\title{
A Simple Way to Reduce the Risk of Being Exposed to COVID-19 Using Instruments for Children
}

\author{
Hery Sumasto* (D), Subagyo Subagyo, Bambang Hadi Sugito, Hadi Purwanto, Nurwening Tyas Wisnu \\ Department of Midwifery, Health Polytechnic of the Ministry of Health, Jawa Timur, Indonesia
}

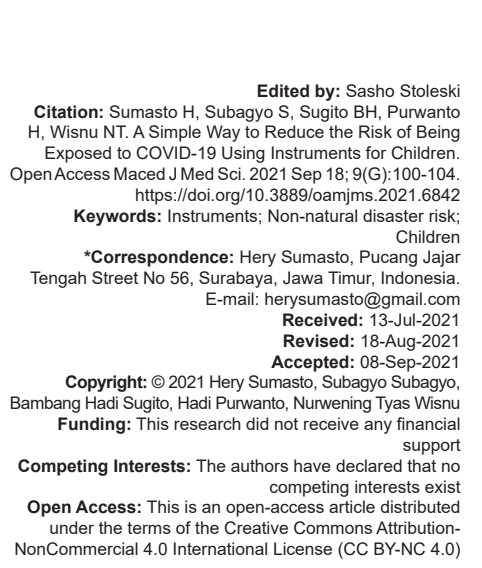

\begin{abstract}
BACKGROUND: Children need to get protection during the COVID-19 pandemic, in accordance with Presidential Regulation 12/2020 on The Determination of Non-Natural Disasters.

AIM: The purpose of the research is to develop non-natural disaster risk instruments for children.

METHODS: This type of research is Research and Development. The participant population is divided into 3 roles Focused group discussion participants (20 people), instrument testing (267 respondents), and experts (methodology experts and disaster experts). Instrument development is carried out in five stages, namely: (1) Instrument evaluation (2) development; (3) experiment; (4) socialization; and (5) recommendations.

RESULTS: The results showed that from 32 valid items, 25 items were all reliable because the Cronbach alpha value was above 0.7 . Not valid for seven items. The results of the instrument trial of 267 children, who had the potential to be exposed to COVID-19 were $69 \%$ who were not exposed to $31 \%$. Of the $69 \%$, strong exposure is $2 \%$, high exposure is $15 \%$ and medium exposure is $83 \%$.

CONCLUSION: The developed non-natural disaster risk instrument can be used to assess disaster risk for children. The instrument works well, has efficiency, functionality and usability. Outputs: (1) Disaster risk instruments for children; (2) intellectual property rights; (3) publication of international journals, and (4) monograph books.
\end{abstract}

\section{Introduction}

Children's risk of disaster is influenced by three factors, namely, potential hazards, vulnerability level, and capacity [1]. The risk of disaster is determined by the size of the potential disaster and the level of vulnerability of the community. While, the factor that mitigates the risk of disaster is the capacity that is the potential of the community [2].

The vulnerability of the child facing disaster is determined by the following elements: (1) The pattern of family care; (2) parental/family supervision; (3) supervision of teachers; (4) weakness/physical disability in the child; (5) psychological condition (mental disability); (6) children's motor activities (7) types of children's games, and (8) nutritional status of children [3]. Good mitigation can minimize the risk of disaster in children so that priority mitigation interventions can be planned [4].

The instruments of disasters that exist today are instruments of natural disasters. In the face of the COVID19 pandemic, there is no instrument of disaster risk for children in the face of non-natural disasters. Based on the background above, it is necessary to conduct research to develop non-natural disaster risk instruments for children.
Thus, interventions can be carried out appropriately based on the priority scale of a child's vulnerability. So far there has been no similar research.

\section{Materials and Methods}

This study used a qualitative approach, with research and development ( $R$ and $D$ ) methods, namely, developing an instrument, which was originally an instrument for disasters in general, but was developed into a special disaster risk instrument for children. The development of the instrument in this research was carried out in five stages, as shown below:

Figure 1 shows the research scheme carried out from the beginning to the end of the research. The final results of this study will then be followed up in a pyramid overview of children's vulnerability through usefulness and hardness approaches. Population: Subjects of FGD participants as many as 40 respondents, namely target- 1 as many as 20 people, target- 2 as many as 20. Experts in this study are methodology experts and children disaster experts. 


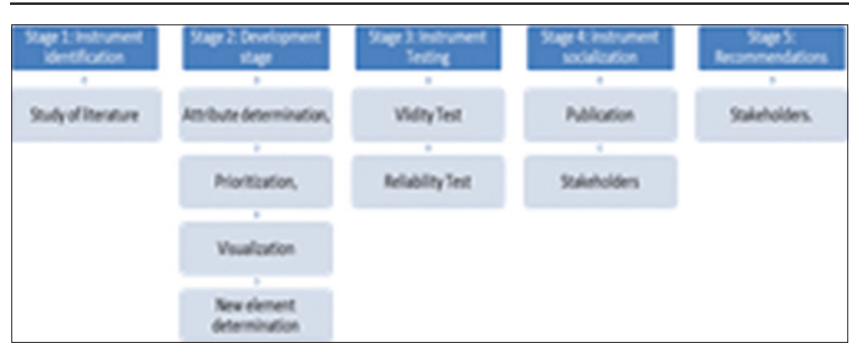

Figure 1: Research instrument development scheme

\section{Results}

Time: This research was conducted from May 2020 to October 2020. The development of instruments in this research was carried out in five stages, namely: Stage 1: Identification of instruments; Stage 2: Development stage (consists of: attribute determination, priority determination, visualization, determination of new elements [21]; Stage 3: Instrument Testing; Stage 4: instrument socialization; and Stage 5: Recommendations.

The results of this study will be described on: (1) The overview of the research; (2) results and analysis of research in phase $1 ;(3)$ the results of research and analysis in phase 2; and (4) research findings. are as follows:

The characteristics of Group 1 FGD participants

Table 1: Characteristics of FGD participants

\begin{tabular}{lll}
\hline Age & $45 \%(25-40$ years) & \\
Gender & Man & $75 \%$ \\
& Girl & $25 \%$ \\
Education & Bachelor & $30 \%$ \\
Length of work & $3-10$ years & $57,50 \%$ \\
Job Category & Honorary staff & $40 \%$ \\
\hline
\end{tabular}

Table 1 shows that respondents with productive age category, undergraduate education, and work experience are long enough as child observers, so that they have the capacity to become FGD participants.

Characteristics of FGD Group 2 participants are seen in terms of age, gender, length of work, last education and employment status. Where the results showed $40 \%$ aged $25-40$ years, $10 \%$ were male, $90 \%$ were female; as many as $70 \%$ of participants have a bachelor's degree; a working period of 3-10 years as much as $70 \%$, and civil servants as much as $45 \%$.

This shows that respondents with productive age category, undergraduate education, and work experience are long enough as child observers, so that they have the capacity to become FGD participants.

\section{Evaluation of disaster instruments in} children

Disaster instruments for children in the approach of COVID-19 non-natural disasters do not currently exist. From the results of the study obtained seven standard components of disaster devices for children, among others: (1) Economic status; (2) knowledge of disaster risk; (3) attitudes about disasters; (4) availability of facilities and infrastructure; (5) the existence of an organization or institution; (6) disaster risk level; and (7) disaster risk reduction behavior [5].

Phase 1 of FGD activities is carried out with the aim of adding information to researchers about the condition of disaster instruments in children, namely; non-natural disasters Covid 19. This FGD activity was divided into two groups held on August 4. Year 2020 in discussion class of Study Program D 3 Magetan Midwifery. Group 1 consists of 20 participants and group 2 consists of 20 participants.

Expert opinion on the development of disaster instruments in children in the prevention of COVID-19 are: (1) Of the three disaster risk variables, it is necessary to explain in the form of seven concepts of disaster causes in children that cannot be used during the COVID 19 pandemic because they need to be updated; (2) in the approach of COVID-19 instruments, from three aspects of disaster risk can no longer be clearly distinguished, because these three aspects can intersect as the cause.

From three aspects described in seven concepts of pre-disaster instruments for children, namely for problem (1) economic status; (2) knowledge of disaster risk; (3) attitudes about disasters; (4) availability of facilities and infrastructure; (5) the existence of an organization or institution; (6) disaster risk threat level, and (7) disaster risk reduction behavior (PRB) refers to prevention approach, breaking the chain of COVID-19 transmission.

Furthermore, each instrument item is tested for validity and reliability. Test validity using Pearson Product Moment by looking at Sig 2 tailed results. It is said to be valid if the value of the sig test result is $<0.05$ and is said to be valid if the sig level is more than 0.05 . The instrument grain reliability test is performed by looking at alpha Cronbach. It is said to be reliable if the value of Cronbach's alpha item is more than 0.7 .

Of the 32 instrument items, 25 items are valid because the sig value of two tailed is $<0.05$. All valid items are subject to confirmation of a CA test value above 0.8 to be reliable. A total of seven instrument items are invalid and unreliable.

Results and Analysis of Research Phase 2

\section{Characteristics of respondents who tested the instrument}

This section describes the characteristics of 267 respondents based on socioeconomic conditions, 
age of the child, number of siblings, gender, and age of the mother. Respondents in this research trial were 267 mothers who had toddlers. From the table above, it can be explained that as many as $27.7 \%$ are prosperous families with indicators of owning a private vehicle, husband and wife in a family who have a job and a fixed income, and never get direct cash assistance (BLT). From the government, of the 267 respondents, 55\% were women and $45 \%$ were men. Of the 267 toddlers have the most siblings 1 is $64 \%$. While, those who have more than three siblings as much as $2 \%$. The average age of the parents is $31.7 \%$ with a maximum age of 54 years and a minimum of 17 years.

The steps taken to determine the risk of disaster in children through the instruments developed are as follows:

Table 2: Perform assessments based on child risk

\begin{tabular}{llll}
\hline No & Risk Category & Variables and Instrument Items & Results Obtained \\
\hline A. & Potential Exposure & F1 = Member of positive group & 1. Strong exposure (3) \\
& & F2 = Positive Neighbors & 2. High exposure (2) \\
& & F3 = positive parent friend & 3. Moderate Exposure (1) \\
B & Risks due to activities, & 1. A1, A2, A3, A4, A5) & High score 11-16 \\
& knowledge and & 2. B1, B2, B3, B4, B5, B6 & Moderate score 6-10 \\
& attitudes & 3. C1, C2, C3, C4, C5 & Low score 0-5 \\
C $\begin{array}{l}\text { Availability of means, } \\
\text { participation and DRR }\end{array}$ & 1. Item D1, D2, D3, D4 & 1. High score 10-13 \\
& 2. E2, E3 & 2. Moderate score 5-9 \\
behavior. & 3. G1, G2, G3, G4, G5, G6 & 3. Low score 0-4 \\
\hline
\end{tabular}

From the table 2, it can be seen that: classifying the variables into three strata of risk, namely:

- $\quad$ Potential Exposure

- Risks due to activities, knowledge, and attitudes

- $\quad$ Availability of facilities, participation, and behavior of PRB

- $\quad$ Specify the percentage of risk per question item.

- $\quad$ Provide meaning/justification for each item.

- Identify items of each risk strata.

By using the instrument that has been developed, it can show the level of exposure of children to potential disasters, categorized into three potential exposures to disaster risk, namely: strong exposure, high exposure, and moderate exposure. Specify the favorites and dislikes of each instrument item. Of the 32 instrument question items, 14 were supported, while 18 were less liked.

These further recommendations are made for weaknesses or things that have not been produced in this study. Some recommendations that can be submitted include: (1) Research needs to be done by applying information technology, so that the risk score in children can be seen directly on social media applications; and (2) as suggested in expert discussions and consultations. The approach to instrument development with the DUP needs to be further researched.

The results of research on the development of disaster risk instruments are as follows: (1) International journal publications reputable to: Journal of Global Pharma Technology; (2) Intellectual Property Rights (HAKI). HAKI has been obtained by Registration Letter
Number EC00202045464, application dated November 1, 2020, author name: Hery Sumasto, Subagyo, Bambang Hadi Sugito Additional output is a monograph book with an ISBN.

\section{Discussion}

Disaster risk is determined by hazard, vulnerability and capacity. Threats can be geographical conditions, rainfall, and potential landslides. Vulnerability of disasters can be among others: Psychological aspects, physical condition of the child, and socioeconomic aspects of the family. Capacities include: Parental education level, employment and family nutritional status. The risk of disaster in children is directly proportional to the multiplied threats and vulnerabilities, and is inversely proportional to the capacity of toddlers [5].

Children are part of a society classified as high risk or vulnerable. They need to prepare themselves well in order to have adequate capacity in dealing with natural disasters. The level of preparedness of the community to deal with disasters is influenced by the level of education. People with high school and university education tend to get higher preparedness index scores than those educated in junior high school and elementary school [6].

Communication facilities play an important role in disaster mitigation. With the presence of means of communication is very possible to prevent the reduction of adverse impacts of natural disasters. The means of communication carried out by the family at this time to save the child are good enough and adequate. A total of $88 \%$ have used mobile phones as access to social media communication. Advances in communication and IT technology can provide information immediately in the event of a disaster.

Children's activities can increase vulnerability to disasters and disasters. Hyperactive children are more adventurous, have a high curiosity, so potentially experience vulnerability, and disaster [7]. Therefore, supervision from parents is also important to note. The physical vulnerability of the child is affected by nutrition. Malnourished children have higher vulnerability compared to children with adequate nutrition. Children will find it difficult to do activities and avoid the dangers that come [8].

The capacity of children under five to survive disasters is determined by the level of parental education, employment and socioeconomic conditions of the family as well as the nutritional status of the family [9].

The age of the child also affects the child's ability to deal with disasters. With age, the maturity and 
coordination of the child's motor muscles will increase. So that the more mature the motor strength of the child will improve the children's ability in dealing with disasters. Parenting patterns also play an important role in determining children's capacity in dealing with disasters. Children who are highly spoiled and protected tend to have low survival abilities. Therefore, allowing children to have difficulty actually provides opportunities for children to survive disasters and disasters [5].

Increasing age of toddlers is expected to have the ability to defend themselves from the threat of disaster. But in general, the number of accidents increases with the age of toddlers [10]. Therefore, prevention and education of domestic safety is needed so that children avoid disasters and disasters.

Development of non-natural disaster instruments for children. The development of disaster risk instruments in children is carried out in three ways, namely, conducting literature studies, Focus Group Discussions (FGD) and consulting with experts. Instrument development is focused on handling the COVID-19 pandemic in 2020. The COVID-19 pandemic occurred at the end of 2019, and was first announced in Indonesia by President Joko Widodo on March 2, 2019. With the announcement of the first person in Indonesia to contract COVID-19, there has been an extraordinary change in terms of disaster risk in children. The risk of disaster in question is the risk of non-natural disasters (covid 19). Therefore, it is necessary to prepare COVID19 disaster instruments for children.

Based on the previous disaster instruments for children, there are seven concepts that need to be described in variables and statement items in the nonnatural disaster risk approach. Disaster management instruments for children cannot be used during the COVID-19 pandemic so they need to be developed. On variable knowledge about disaster risk, it is necessary to add items that can decide to prevent the transmission of COVID 19. Disaster management instruments for children for knowledge problems about disaster risk found have not yet referred to the prevention approach, breaking the chain of COVID-19 transmission.

Expert opinion on the development of disaster instruments in children in the prevention of COVID19 is: From the three variables of disaster risk, it is necessary to explain in the form of 7 concepts of disaster causes in children that cannot be used during COVID 19. pandemic because it needs to be updated. In the COVID 19 instrument approach, from 3 aspects of disaster risk there is no more clear distinction, because these three aspects can be a cross as a cause. Of the three aspects described in seven concepts of pre-disaster instruments for children, namely, for problem (1) economic status; (2) knowledge of disaster risk; (3) attitudes about disasters; (4) availability of facilities and infrastructure; (5) the existence of an organization or institution; (6) Disaster risk level, and (7) disaster risk reduction behavior (PRB) refers to prevention approach, breaking the chain of COVID-19 transmission.

The results of consultation with experts state that COVID 19 risk measurement instruments are different from other risk instruments. The difference is because there is potential that at any time can cause the child to contract. Therefore, the test of validity and reliability is not very important.

Reliability tests are also performed on all instruments to obtain reliable instruments by conducting $\mathrm{CA}$ tests. The principle of arranging instruments according to Nursalam (2017) is validity and reliability. The principle of validity is measurement and observation which means the principle of reliability of instruments in collecting data [11]. Validity refers to the aspect of accuracy and accuracy of measurement results. There are five sources of proof of validity, namely, content, response processes, internal structures, relationships with other variables, and their consequences. There are three types of validity, namely the validity of the content (validity of the content), the validity of the criteria (validity of the criteria), and the validity of the construct (the validity of the concept) [12]. The validity of the content is defined as the extent to which the instrument assessment element is relevant and represents the target construction for a particular objective assessment. The validity of content is validity estimated through conformity testing or relevance of test content through rational analysis by competent panels or through expert judgment. Reliability is the similarity of measurement or observation results when facts are measured or observed many times in different times [13].

Dissemination of the results of the development of this important instrument is carried out in order to be immediately used to assess the risk of non-natural disasters in children. This is to support the rights of children as stipulated in Law No. 35/2014 on Child Protection. Also referring to Presidential Regulation $12 / 2020$ concerning the Determination of Non-Natural Disasters the Spread of COVID-19 as a National Disaster, namely, in Article 59: Governments, Local Governments, and other state institutions are obliged and responsible to provide Special Protection for Children (including) in emergency situations [14].

Based on the results of FGD, recommendations for the development of disaster risk instruments for children are the development of disaster risk instruments for children can be used to conduct disaster risk assessments on children [15]. This recommendation is based on the results of instrument testing related to non-natural disaster risk in children. All respondents were able to fill the instrument development well. Most respondents also argued that the development of such instruments is good and easy to fill out Google forms. So it meets the principles of functionality, efficiency and usability aspects. 


\section{Conclusion}

$\bullet$

The results of the evaluation of the previous instrument are known to only be used to measure the risk of natural disasters, while in the case of non-natural disasters COVID 19, there is no such thing, so this research needs to be developed.

- $\quad$ There are seven variables currently used for disaster risk instruments in children, namely socio-economic, activities, knowledge, attitudes, infrastructure, existence of organizational institutions, threat level, and behavior.

- Instruments developed consist of 32 items derived from six variables developed, namely: (1) Activity; (2) knowledge; (3) attitude; (4) infrastructure; (5) the existence of institutional organizations; (6) threat level, and (7) behavior. While socioeconomic variables respondents / children.

Validity and reliability test results show that out of 32 question items there are 7 invalid items because Sig two tailed above 0.05. While, 25 items were declared valid because the value of sig two tailed $<0.05$. All valid items are tested for reliability by looking at Cronbach alpha the result is all he is at 0.07 meaning reliable.

- Development of disaster risk instruments in children has good function in terms of functionality, efficiency, and usefulness

\section{References}

1. Sumasto SH, Wisnu NT, Ngestiningrum AH, Setiawan, Sugito $\mathrm{BH}$, Najib M. Trauma healing during the earthquake disaster emergency response phase in Lombok, Indonesia. Indian J Forensic Med Toxicol. 2019;13(4):1745-8.

2. Chandra RK, Supriharjo RD. Rob flood disaster mitigation in North Jakarta. J Tek Pomits. 2013;2(1):25-30.

3. Sumasto H, Wisnu NT, Surtinah N. Development of instruments to detect disaster risk in children under five hery. Heal Notions. 2018;2(2):279-83.

4. Suparmini S, Setyawati S, Sumunar D. Disaster mitigation based on local wisdom of the baduy community. J Penelit Hum. 2014;19(2):47-64. Available from: http://journal.uny.ac.id/index.

Author Query???

AQ1: Kindly provide the replace image for figure 1 php/humaniora/article/view/3511

5. Tarnoto N. Permasalahan-problems faced by the school of inclusion education organizers at the sd level. Humanit (Jurnal Psikol Indones). 2016;13(1):50-61. Available from: http://journal. uad.ac.id/index.php/HUMANITAS/article/view/3843\%5Cnhttp:// journal.uad.ac.id/index.php/HUMANITAS/article/ download/3843/2111

6. Fitriningsih K. Relationship between Formal Education Level and Preparedness in Facing Earthquake Disasters of Jabung Village Community, Gantiwarno District, Klaten District. In: Fitriningtiyas K, editor. Fakultas Keguruan dan IImu Pendidikan Universitas Muhammadiyah Surakarta. Surakarta; 2014. p. 17. Available from: http://eprints.ums.ac.id/30020/1/03_DEPAN.pdf

7. Asyhari A, Fisika P, Lampung B, Lampung B, Budaya A, Asesmen $\mathrm{I}$, et al. Development of science literacy assessment instruments based on Islamic values and Indonesian culture with a contextual approach. LENTERA Pendidik. 2019;22(1):16679. Available from: http://journal.uin-alauddin.ac.id/index.php/ lentera_pendidikan/article/view/6437

8. Astuti A. Implementation of Disaster Preparedness School Program at SMA Negeri 1 Karanganom Klaten; 2015.

9. Hidhayah Nur Damayanti. Study of Individual and Household Preparedness in Facing Tsunami Disaster in Grabag District. Vol. 44. Purworejo Regency; 2015.

10. Nursalam N, Harsaktiningtyas $\mathrm{K}$, Kurnia ID, Fadhillah $\mathrm{H}$, Efendi F. Effect of bibliotherapy on self-concept in children. Indian J Public Heal Res Dev. 2018;9(11):612-6. Available from: https://www.scopus.com/inward/record.uri?eid=2-s2.085058143539\&doi=10.5958\%2f0976-5506.2018.01526.7\&part nerID $=40 \&$ md5 $=649$ eefb206b31a9bed8a002e5a0f3a0d

11. Nursalam N, Octavia M, Tristiana RD, Efendi F. Association between insomnia and social network site use in Indonesian adolescents. Nurs Forum. 2019;54(2):149-56. Available from: https://www.scopus.com/inward/record.uri?eid=2-s2.0$85058061226 \&$ doi $=10.1111 \% 2$ fnuf. $12308 \&$ partnerlD=40\&md5 $=8 \mathrm{~b} 1 \mathrm{c} 9 \mathrm{c} 2622952 \mathrm{~d} 342 \mathrm{~b} 6$ eaa088f552a3b

12. Susilaningrum $R$, Utami $S$, Nursalam $N$. Analysis of factors related to communication skills in midwifery students. Indian J Public Heal Res Dev. 2018;9(12):612-7. Available from: https://www.scopus.com/inward/record.uri?eid=2-s2.085061598078\&doi $=10.5958 \% 2 f 0976-5506.2018 .01905 .8 \&$ part nerlD $=40 \& m d 5=5 f 911 f 4 a c a 4 e d 5 f f 8 f 874 b 19 c 7 a 05 e 4 f$

13. Afzali M, Viggers $S$. Full-scale simulation may be used to train medical students in disaster medicine. Trends Anaesth Crit Care. 2015;5(1):17-22. Available from: http://dx.doi.org/10.1016/j. tacc.2014.11.005

14. Sumasto H, Sulikah NT. Development of assessment instruments for disaster resilient campus capacity. Heal Notions. 2019;3(7):321-8. Available from: http://heanoti.com/index.php/ $\mathrm{hn} /$ article/view/hn20225

15. Sumasto H, Wisnu NT. The Follow up Taken by Women who have Undergone "Visual Inspection with Acetic Acid (VIA) Test with Positive Results. Vol. 2. Indonesia: Health Polytechnic of Surabaya; 2016. p. 20-2. 